\title{
Authentic Leadership and Employee Performance
}

\author{
Zafira Yasmin ${ }^{1, *}$ Budi Santoso ${ }^{2}$, Yana Setiawan ${ }^{3}$
}

\author{
${ }^{1}$ Universitas Pendidikan Indonesia \\ ${ }^{2}$ Universitas Pendidikan Indonesia \\ ${ }^{3}$ Universitas Pendidikan Indonesia \\ *Corresponding author.Email: zafirayasmin3@gmail.com
}

\begin{abstract}
The problem of the research is that there is a low employees performance in the finance work. It was found in the implementation of activities and use of the budget which still face the obstacles such as the employee performance in submitting the SPJ / SPTB to the directorate of finance. The purposes of the research are: 1) to know how authentic leadership and employee performance, 2) to know how does authentic leadership influences employee performance. The research method used was quantitative approach. The subjects of the research were employees of the Directorate, Faculty and Study Programs financial work units at the Universitas Pendidikan Indonesia totaling 114 people. Data analysis techniques used was simple regression combined with SPSS and AMOS. The results of the research showed that: 1) authentic leadership was in the effective category, and employee performance was in the high category, 2) authentic leadership had a positive effect on employee performance.
\end{abstract}

Keywords: Authentic Leadership, Employee Performance.

\section{INTRODUCTION}

Every work unit at Universitas Pendidikan Indonesia must submit financial reports as a form of accountability for performance accountability. There is a problem in the financial statements of the work unit at Universitas Pendidikan Indonesia. One of the problems is the low absorption of the funds in end the year. It can be seen from data table 1 that presented below reported by Universitas Pendidikan Indonesia 2016.

Table 1. The Fund Realization Based on Funding Sources

\begin{tabular}{|l|l|l|l|}
\hline No & $\begin{array}{c}\text { Sources of } \\
\text { funding }\end{array}$ & $\begin{array}{c}\text { Fund Allocation } \\
\text { (Rp) }\end{array}$ & $\begin{array}{c}\text { Fund Realization } \\
\text { (Rp) }\end{array}$ \\
\hline 1 & APBN & 222.282 .934 .000 & 209.705 .399 .911 \\
\hline 2 & BPPTN bh & 70.179 .000 .000 & 70.165 .000 .000 \\
\hline 3 & NonPNBP & 429.807 .776 .428 & 406.361 .332 .997 \\
\hline & Jumlah & 722.269 .710 .428 & 686.231 .732 .908 \\
\hline
\end{tabular}

Based on the data above, it can be analyzed that the realization all the of th funds had reached $95.01 \%$. The realization of the use of the funds as of 31 December 2016 amounted to $\mathrm{Rp} 686,231,732,908$ in each of realization. However, there is still a difference in the budget absorption capacity of the work units at Universitas Pendidikan Indonesia. Other problems come from the implementation of agenda and the use of the funds that still find some obstacles like the slow the work unit in submitting the SPJN and SPTB to the decorate of the finance. Thus, it will obstruct the disbursement process in the next period.

Based on the results of the research, It can be explained that employee performance can be affected by the internal environment and external environment. From an external perspective performance is influenced by leadership factors. Job resources are also various things in the employee environment that are able to influence employee performance such as autonomy, performance feedback, social support, supervisory coaching, leadership style, organizational climate, incentives, etc [1].

More than two decades, transactional/transformational leadership has become the "new paradigm" theories and has occupied center stage [2]. Transformational leaders exhibit charismatic behaviors, arouse inspirational motivation, provide intellectual stimulation, and treat followers with individualized consideration [2]. Also, Authentic leadership can incorporate transformational, charismatic, servant, spiritual, or other forms of positive leadership. However, authentic leaders are not necessarily transformational or charismatic. It caused that they influence follower awareness from a values/moral 
perspective and energize followers by creating meaning and positively constructing reality for themselves and followers [2]. However, it should have better understanding of the followers' personal and contextual factors that may affect the impact of autentic leaderships on follower performance. It is a line with reference [3] that states authentic learders have to develop and influence their follower. In addition, authentic leadership as a style can influence, directly or indirectly, employees' attitudes and behaviours [4]

Authentic leaders refer to individuals who are deeply aware about how they think and behave perceived by others as being aware of their own and others' values/moral perspective, knowledge, and strength; aware of the context in which they operate; and who are confident, hopeful, optimistic, resilient, and high on moral character [2]. Authentic leadership is trained by some factors such as, self-knowledge, self-regulation, self-esteem, self-efficacy, self motivation, self identity self-realization/development [2].

Performance is an effort to complete the work carried out by individuals in the organization. It is related to employee behavior and attitude so that it is perceived as a condition or level that can be achieved by someone in carrying out their duties. Therefore, it can be defined as individual behavior in the completion of each task in its work [5]. It basically refers to what employees does or don't do [6].Besides, it is a real behavior that is displayed by everyone as a work achievement produced by employees in accordance with their role in the company [7]. Contextual performace is defined as those behavior that contribute to the organization's effectiveness by providing a good environment in which task performance can occur. Performance is about behavior or what employees do, not about what employees produced or the outcome of their work [8].

Performance is the accomplishment, execution, carrying out, working out of anything ordered of undertaken. High performance related to the appropriate behavior, especially discretionary behavior, and the effective use of the required knowledge, skills and competencies. It means that both behavior and result became a unity that relate to each other in employee performance. Behavior emanate from the performer and transformnational performance from abstraction to action [9].

Based on the explanation above it can be concluded that performance has several meanings, namely 1) performance is the result or work performance of each individual for each task and responsibility or role performed in the organization, 2) performance is an evaluation of the results achieved and carried out over a certain period of time, 3 ) performance becomes an ability of the organization to achieve goals by using resources efficiently and effectively.
According to reference [8] page 81, was his study entitled performance assessments describes that there are some aspects that influence the employee performance which covers the behavior such as 1) Persisting with entusiasm and exerting extra effort as necessary to complete one's own task activities succefully, 2) Volunteering to carry out task activities that are not formally part the job, 3) Helping and cooperating with other, 4) Following organizational rules and procedures. 5) Endorsing, supporting, and defending organizational objectives.

\section{METHODS}

This research analyzed the effect of authentic leadership on employee performance. The subjects of the research were the financial employees in Universitas Pendidikan Indonesia, in which involved 114 financial employees. The unit of analysis in this study is individuals, namely Finance employees. The population in this study were financial employees at the Indonesian University of Education as many as 114 people. The sample in the research was 114 people. The technique of the data analysis used was simple regression. The hypothesis in the research was that authentic leadership that influences employee performance.

\section{RESULTS AND DISCUSSION}

\subsection{Characteristics of Respondents by Gender}

The Characteristics of respondents by sex are presented to provide an overview of the comparison of the number of men and women in financial management employees at the Universitas Pendidikan Indonesia. who were respondents in the study. Characteristics of respondents by sex are presented in the following fig. 1 .

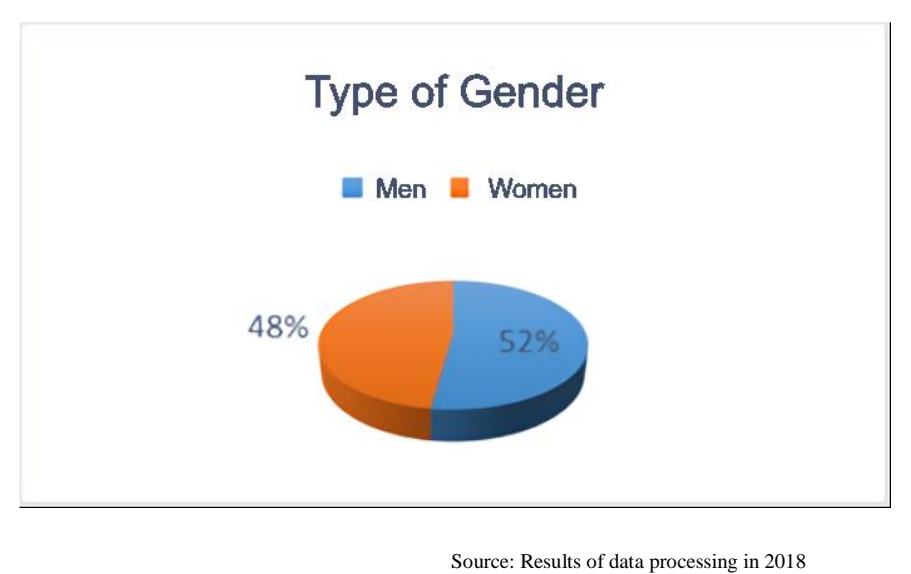

Figure 1 Characteristics of respondents by gender

Based on the fig. 1. above, the most number were male employees as much as $52 \%$ while the number of female employees was $48 \%$. It shows that the financial management staff Universitas Pendidikan Indonesiais dominated by men in carrying out its operations. 


\subsection{Characteristics of Respondents by Age}

Characteristics of respondents by age are presented to provide an overview of the composition of the age of financial management in Univeristas Pendidikan Indoensia. Characteristics of respondents based on employee age are presented in the following fig. 2 .

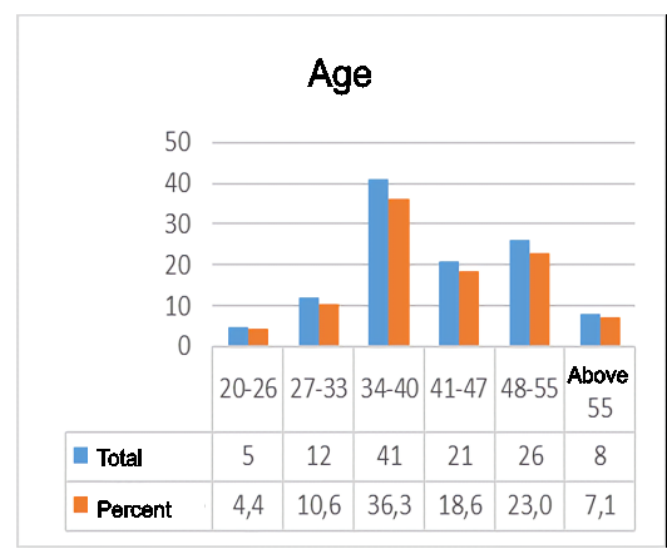

Sumber : Results of data processing in 2018

Figure 2 Characteristics of respondents by age

Based on the picture above, the most number of employees were at the age of 48-55 years as much as $23 \%$ while the fewest number of employees were at the age of 20-26 years as much as $4.4 \%$. It means that PTPN VIII employees were dominated by men at the age of 48-55 years in the implementation of their operations

\subsection{Characteristics of Respondents Based on Recent Education Levels}

Based on the last level of education presented to provide an overview of the composition of the last level of education of financial management employees at the Universitas Pendidikan Indonesia. Characteristics of respondents based on their last education are presented in the following fig. 3 .

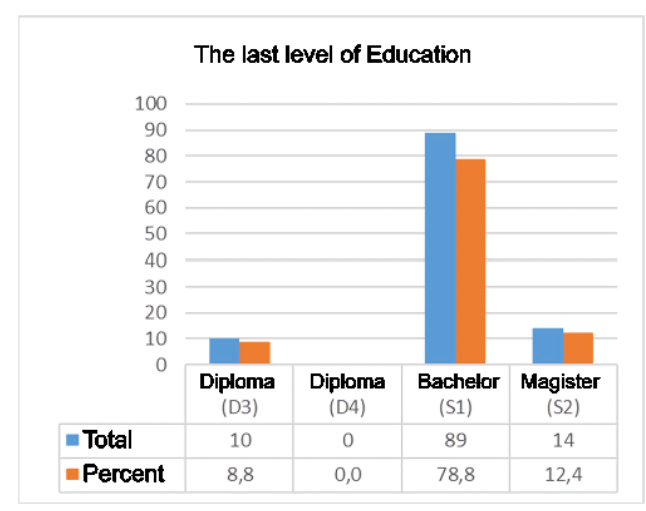

Sumber : Results of Data Processing in 2018

Figure 3 Characteristics of respondents based on recent education levels
Based on the picture above, the largest number of financial management employees at UniversitasPendidikan Indonesia were at the last Bachelor level (S1) which is $78,8 \%$ while the least number of employees were in the latest Diploma (D3) level of $8,8 \%$.

\subsection{The Respondents' Experiences of the Suitability of Financial Work with Recent Education}

Respondents' experience on the suitability of the financial sector with the latest education is presented to provide an overview of the composition of the experience of financial management employees at the Universitas Pendidikan Indonesia, which were used as respondents in this study. Characteristics of respondents based on their last education are presented in the following fig. 4 .

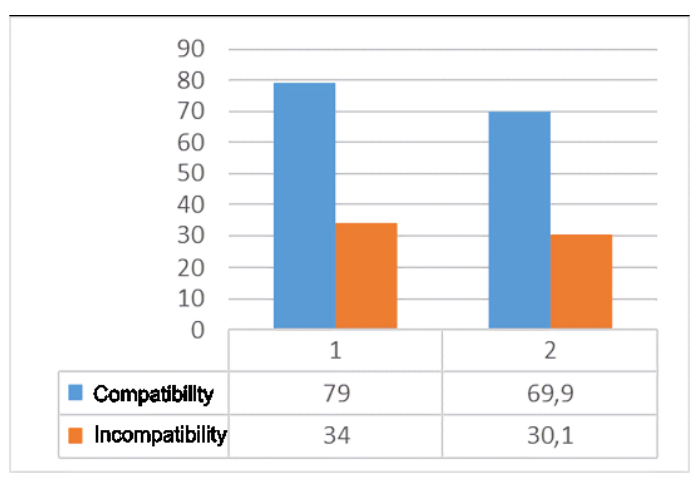

Sumber : Results of Data Processing in 2018 Figure 4 The respondents' experiences of the suitability of financial work with recent education

Based on the picture above, the highest number of financial management employees at UniversitasPendidikan Indonesia stated that it was in line between financial work and the latest education, which was $79 \%$. Whereas the least stated incompatibility between financial work and last education is $69.9 \%$

\subsection{Experiences of Respondents in Managing Finances}

Respondents' experiences about the experience of managing finances were presented to provide an overview of the composition of the experience of financial management employees at Universitas Pendidikan Indonesia. Characteristics of respondents based on their last education are presented in the following fig. 5 . 


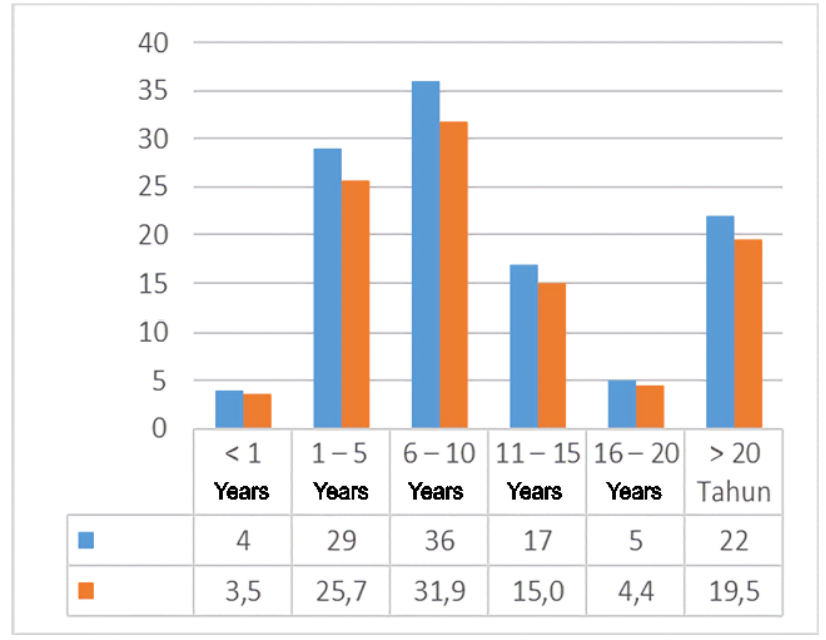

Sumber : Results of data processing in 2018

Figure 5 Experiences of respondents in managing finances

Based on the picture above, the highest number of financial management employees at Universitas Pendidikan Indonesia stated that they had 6-10 years experience in managing finances as much as $31.9 \%$. While at least stated having less than $<1$ year experience in managing finances that is as much as $3.5 \%$

\subsection{The Effect of Authentic Leadership on Employee Performance}

The independent variable in this research was authentic leadership while the dependent variable was employee performance. To test the presence or absence of free influence on the dependent variable, a simple regression test was performed. Based on the results of a simple regression test, the effect of authentic leadership on employee performance was explained in the following table 2.

Table 2. Model Summary

\begin{tabular}{|l|l|l|l|l|}
\hline \multicolumn{5}{|c|}{ Model Summary } \\
\hline Model & \multicolumn{1}{|c|}{$\boldsymbol{R}$} & $\boldsymbol{R}$ Square & $\begin{array}{c}\text { Adjusted } \boldsymbol{R} \\
\text { Square }\end{array}$ & $\begin{array}{c}\text { Std. Error of the } \\
\text { Estimate }\end{array}$ \\
\hline 1 &, $547^{\mathrm{a}}$ &, 300 &, 293 & 3,747 \\
\hline a. Predictors: (Constant), Authentic Leadership \\
\hline
\end{tabular}

Based on the table above, the correlation value was 0.547 . This shows that there is a moderate relationship between authentic leadership and employee performance. While the coefficient of determination was 0.300 . It shows that the effect of authentic leadership on employee performance by $30 \%$, while the remaining $70 \%$ is influenced by other factors.

Currently, leadership has an important role in the organizational environment and the style of supervision adopted by leaders can influence employees' behaviors and attitudes directly or indirectly. It is perceived and valued by many stakeholders as a key element of success, a differentiating factor with strong impact on the achievement of goals [4]. Autentic leadership has a positive effect on follower performance. Previous theory building has indicated that authentic leaders can influence follower performance [3] shown as table 3 .

Table 3. Anova

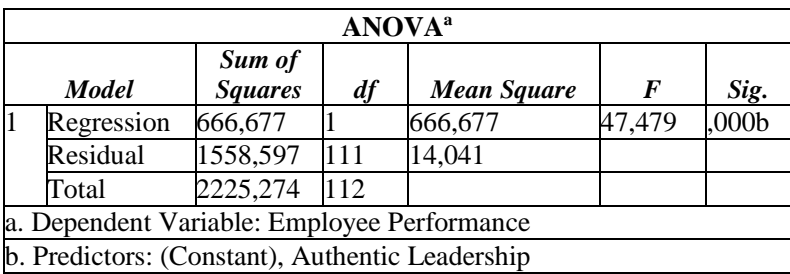

Based on the table above, there wasa significant influence of authentic leadership on employee performance of 47,479 with a significance level with a significance / probability level of $0,000<0.05$. Then the regression model can be used to predict employee performance variables.

It has been linked to a number of positive outcomes at the individual level, including performance, work engagement, creativity [10]. A positive, genuine, transparent, ethical form of leadership, broadly termed authentic leadership (AL), is recognized as a positive approach to organizational leadership that can help meet today's challenges [3].

Table 4. Coefficient

\begin{tabular}{|c|c|c|c|c|c|}
\hline \multirow[b]{3}{*}{ Model } & \multicolumn{3}{|c|}{ Coefficients $^{\mathrm{a}}$} & \multirow[b]{3}{*}{$t$} & \multirow[b]{3}{*}{ Sig. } \\
\hline & \multicolumn{2}{|c|}{$\begin{array}{l}\text { Unstandardized } \\
\text { Coefficients }\end{array}$} & $\begin{array}{c}\text { Standardized } \\
\text { Coefficients }\end{array}$ & & \\
\hline & B & Std. Error & Beta & & \\
\hline 1 (Constant) & 28,520 & 1,930 & & 14,780 &, 000 \\
\hline $\begin{array}{l}\text { Kepemimpinan } \\
\text { Otentik }\end{array}$ & ,433 &, 063 &, 547 & 6,891 &, 000 \\
\hline
\end{tabular}

The coefficient on the constant table was 28.520 , while the authentic leadership value is 0.433 , the regression formula (1).

$\mathrm{Y}=\mathrm{a}+\mathrm{b} \mathrm{X}$ or $28,520+0,433 \mathrm{X}$

The coefficient $b$ was interpreted as a coefficient of regression direction and states the average change in the variable $\mathrm{Y}$ for each change in variable $\mathrm{X}$. It means that was an increasing in value of $b$ positive and decrease if $b$ is negative

$\mathrm{T}$ value of 6.891 with a significance value of 0.000 $<$ of 0.050 , then $\mathrm{HO}$ was rejected and $\mathrm{H} 1$ was accepted. It can be said that there was a significant influence of authentic leadership variables on the performance of financial employees.

\section{CONCLUSIONS}

Authentic leadership is an effective category with the factors which provides a essential contribution through 
combination som factors. Employee performance is included in the high category with the factor that contributes dominantly towards the organizational achievement goals. Thus, it has an influence and enhances the performance of financial employees at Universitas Pendidikan Indonesia. Therefore, Universitas Pendidikan Indonesia is expected to increase the effectiveness of authentic leadership through selfdevelopment factors.

\section{REFERENCES}

[1] F. H. Dyah Ratri I, Hayuningtyas Avin, "Peran kepemimpinan otentik terhadap work engagement dosen dengan efikasi diri sebagai mediator," GADJAH MADA J. Psychol., vol. 1, no. 3, pp. 167179, 2016, doi: 10.22146/gamajop.8814.

[2] K. Klenke, "Authentic leadership: a self, leader, and spiritual identity perspective," Int. J. Leadersh. Stud., vol. 3, no. 1, pp. 68-97, 2007.

[3] J. R. Hackman, "From causes to conditions in group research what is this thing called "group '?," $J$. Organ. Behav., vol. 33, no. 3, pp. 428-444, 2012, doi: 10.1002/job.

[4] A. S. Semedo, A. Coelho, and R. Neuza, "Authentic leadership and creativity: the mediating role of happiness," Int. J. Organ. Anal., vol. 253, no. 3, 2017.

[5] A. D. Timpe, Seri manajemen sumber daya manusia mengelola waktu the management of time. 2002.

[6] R. L. Malthis and J. H. Jackson, "Human resource management (manajemen sumber daya manusia), edisi kesepuluh, terjemahan: Diana Angelica," Penerbit: Salembs Empat, Jakarta, 2006.

[7] V. Rivai and E. J. Sagala, Manajemen sumber daya manusia untuk perusahaan. Dari Teori ke Praktik, Kedua. Jakarta: PT Rajagrafindo Persada, 2009.

[8] H. Aguinis, Perfomance management, Second. Canada: Pretice Hall, 2014.

[9] M. Amstrong, Performance management. Key Strategies and Practical Guidelines, Third. London: Kogan Page, 2009.

[10] J. Lyubovnikova, A. Legood, N. Turner, and A. Mamakouka, "How authentic leadership influences team performance: the mediating role of team reflexivity," J. Bus. Ethics, vol. 141, no. 1, pp. 5970, 2017, doi: 10.1007/s10551-015-2692-3. 